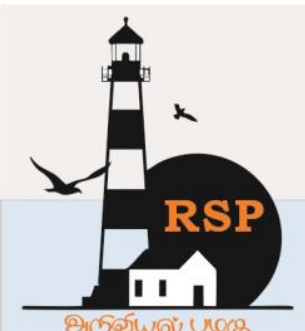

\title{
Designing and Evaluating the Performance Solar Powered Iron Box
}

\author{
C. Anupama, Dr. M. R. Thilakam ${ }^{2}$
}

${ }^{1}$ P.hD Research Scholar, Department of Resource Management, Avinashilingam Institute for Home Science and Higher Education for Women, Coimbatore-641 043, Tamil Nadu, India

${ }^{2}$ H.O.D \& Professor, Department of Resource Management, Avinashilingam Institute for Home Science and Higher Education for Women, Coimbatore-641 043, Tamil Nadu, India

Anupamacoduri@gmail.com ${ }^{1}$

\begin{abstract}
Due to the technological advancement and population and explosion, the world's demand for energy has a rapid growth. So a renewable energy source that is cost-effective, reliable and everlasting must be opted to meet the future energy demands. There are many renewable energy sources out of which solar energy is free of cost. It is also suitable for long-term issues. Due to energy's high demand, the solar industry is developing all over the world. Many other energy sources like fossil fuel are expensive and also have limited applications. It has become a tool to sustain the underprivileged people's life. It also has a great part in developing in the economic status of various countries. Solar industry is the best energy source than other energy sources and a solution to meet the future energy demands as it has various benefits. The various benefits include capacity, cost-effectiveness, accessibility, availability and efficiency. Based on the interest and above view point researcher selected the area of solar energy. This paper on "Designing and Evaluating the Performance of Solar Powered Iron Box" briefly describes the design and performance of the solar powered iron box. A study was conducted in Coimbatore city among four hundred samples using interview schedule for which questionnaire was developed which entailed sociodemographic profile of the participants, solar devices used by them, limitations faced, other device they would like to have operated on solar power etc. During the study it was revealed that majority of participants opted for solar powered device
\end{abstract}

Keywords: energy, solar powered iron box, designing, performance, evaluation

\section{Introduction}

India uses the solar power more than other renewable resources and India has high solar ionization. Solar energy is a renewable energy source, maintenance cost is low, diverse applications, and electricity bill gets reduced through its usage and it also helps in technology development.

Solar energy has various residential applications which include solar heating for swimming pool, solar powered ventilation fans, solar house heating, solar water heater, charging batteries through solar power, solar powered pumps and so on. Adoption of renewable solar energy has various environmental advantages also. It reduces pollution, It is clean source, reduces the usage of water, helps to fight the climate change, reduces non-renewable energy dependence and improves health of humans in long-term.

\section{Objectives of the study}

- To assess the solar devices used by the households

- To examine the most popular device among the household

- To know the troubles encountered by the household while using the device 
- To design the solar powered device and evaluate its performance

\section{Limitations of the study}

- Due to time constraints study was limited only to the household level of Coimbatore city

- Households living in their own residents were surveyed for data collection

- As the interview schedule was adopted to collect the data, respondents may be biased to certain questions.

\section{Methodology}

The chapter provides research methodology of the work which gives useful information and details regarding the way, a research has been conducted in terms of method employed and procedure followed. The below figure state the overall study type, location, sample selection, and methodological analysis of the study. This research is done in Coimbatore which is well-known for textile industry. The survey was done with households using at least one solar device with sample size of 400 in the four regions of Coimbatore.

From the fig.1 schematic representation of methodology it is clear that the study is divided into two phases. The following phases are explained briefly below.

The 1st phase of the study is Household Survey. In the first phase of the study, data was collected from households who are using at least one solar device. Information were collected regarding solar devices used by them, purpose of using solar devices, their perception on the contribution of solar devices in improving the environment, ease of operation, problems encountered while operating the device, an innovative solar device they would prefer to be introduced in the market. Details of population using solar devices were gathered from Tamil Nadu Energy Department Agency (TEDA).The households were contacted either through telephone or in person based on the convenience of the investigator and the respondent. The purpose of the research was explained to them. When the information was gathered in person the investigator made use of the opportunity to observe the solar gadgets possessed by the respondents.

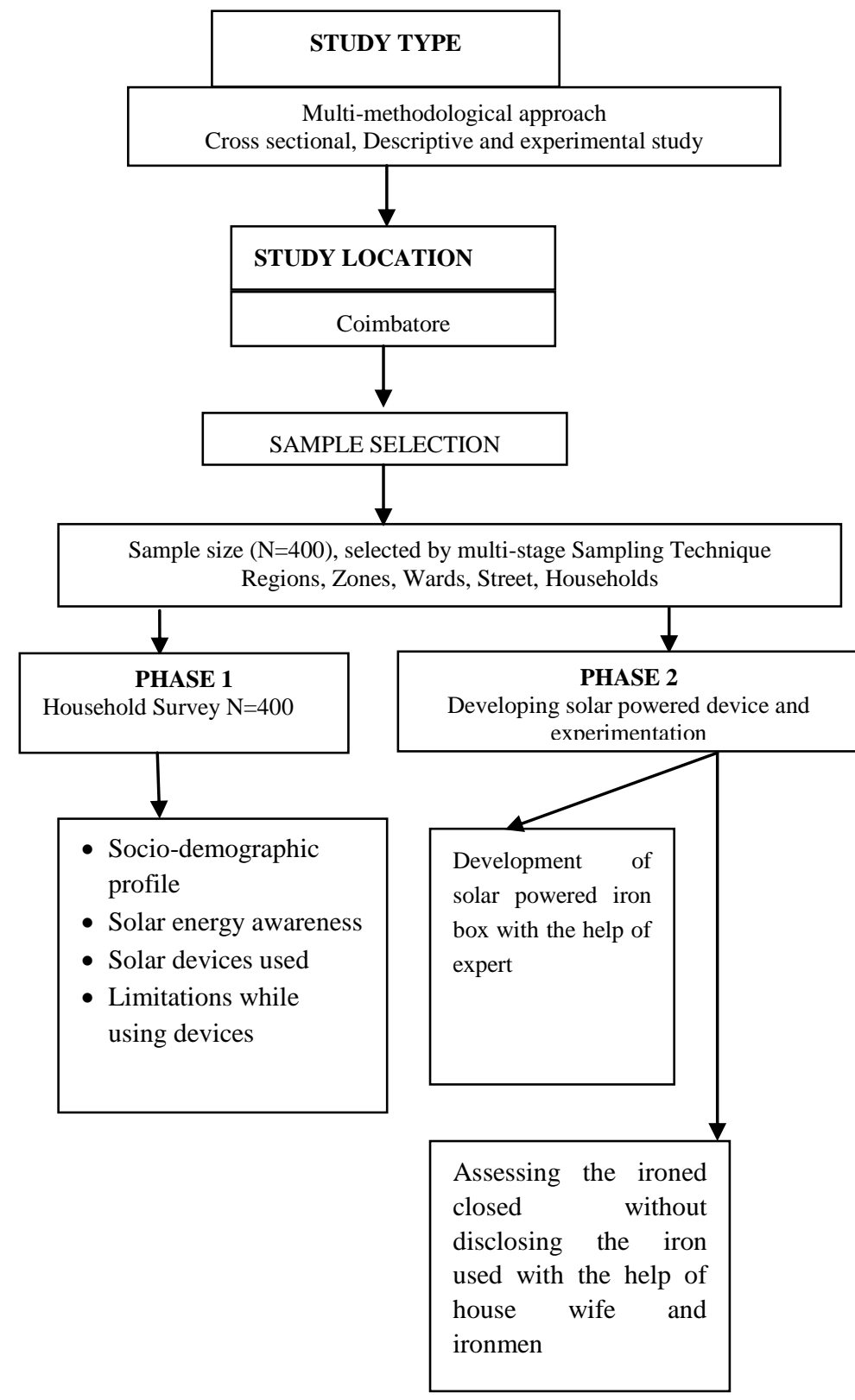

Fig.1. Methodology schematic representation

The 2nd phase of the study was developing a solar powered iron box. Based on the suggestions given by the surveyed households it was decided to design an Iron box operated on solar energy for household use with the help of experts. Solar powered iron box will be helpful to save electricity. Cost will be estimated in developing the solar powered iron box. The weight of the iron box, the size, ease of handling, storage, performance and its efficiency in operation, will be kept in mind. The product will be evaluated by experimenting with the help of experienced homemakers and ironmen. They will be instructed to iron fixed number of clothes using the common 
electrical iron and the designed solar iron box. They will be given a prepared score card and will be asked to evaluate the product based on ease of operation and output of the product.

\subsection{Construction of Iron box}

Solar powered iron box was developed for household purpose with battery backup. For creating solar power iron box experts were enquired.

Materials required for constructing solar powered iron box are mentioned below:

- Acrylonitrile Butadiene Styrene plastic make for handle

- Non-stick coated, aluminum casting plate for heat

- (1.4-2) Aluminum coil for heating

- 120watts heating up coil

- $12 \mathrm{~V}$ Dc and 10 ampere current flow

- $(2 X 2.5 \mathrm{sqmm})$ cable used

- Crocodile connector used for supply through battery

- $5 \mathrm{~mm}$ led (red) for indication purpose is used

4.2 Working principle of solar powered iron box

Solar powered iron box is linked to solar panels in figure. DC electricity is generated when the sunlight falls on the solar panels. This electricity charges the in-built battery in solar powered iron box. When the battery filled with charge, it powers the connected electrical load-DC fan, light, TV and phone charging. This gives the energy consumption for the solar powered device and it makes less energy consumption.

\section{Result and discussion}

During the research work it was found that households were using multiple solar devices among which $70.5 \%$ of hous households were using solar home lighting, $48.5 \%$ were using solar water heater and remaining were using solar UPS, pump and AC. It was examined that most popular device among households was solar home lighting. The study also revealed that households were facing multiple troubles while operating the solar devices. Solar devices are dependent on the intensity of the sun, said by $57.9 \%$ of households where as $50.3 \%$ of household said solar devices is time consuming. Thirty eight point six percent of households said solar devices comes with exorbitant cost. Twenty eight point nine percent households said that their device is ineffective at night, twenty eight point four said the device have limited storage capacity.

\section{Evaluation of solar powered iron box}

\subsection{Aspects of solar powered iron box}

For evaluating the designed solar powered iron box a team of 15 homemakers and 15 cloth ironing workers were formed. They all were given a chance to iron the clothes using solar powered iron box. After which a checklist regarding aspects and operation of device were given to them to record their view.

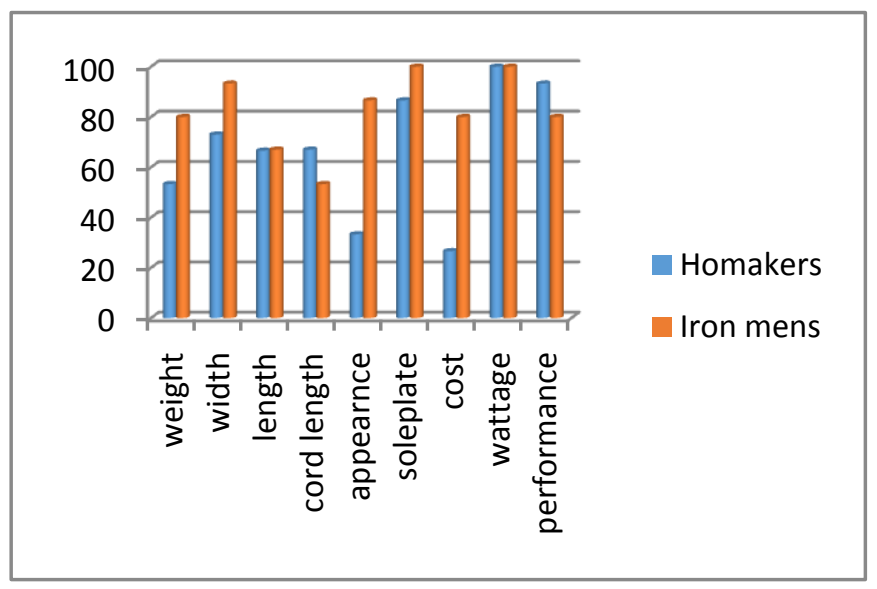

Fig.2. Aspects of devices

Above Fig 2 depicts the aspects of devices from which homemakers and iron men are satisfied. It is seen that both homemakers and iron men are satisfied with performance of the devices. $93.3 \%$ of homemakers said they are satisfied whereas 80 $\%$ iron men said they are also satisfied with the performance of the devices. It was found that homemakers were not happy with the cost of the device as $73.4 \%$ of homemakers felt that cost of the iron box is high but iron men seemed to be satisfied because it was one time investment for them.

\subsection{Performance of the solar powered iron box}

Fig 3 clearly shows that both home makers and iron men were $100 \%$ satisfied with quick heating quality of the device and also it is safe to use on all types of fabrics. Hundred percent and Ninety three point three percent iron men and homemakers said that solar powered iron box removes all crease from the cloths respectively. It was revealed during the evaluation of device that as it is new device for both homemakers and iron men they faced certain difficulties in operating the device. 


\section{www.rspsciencehub.com}

According to only $33.3 \%$ of homemakers solar powered iron box occupies less space in their home remaining $66.7 \%$ of homemakers said devices occupies more space to store it whereas among iron men $80 \%$ said solar powered iron box occupies less space in their shop

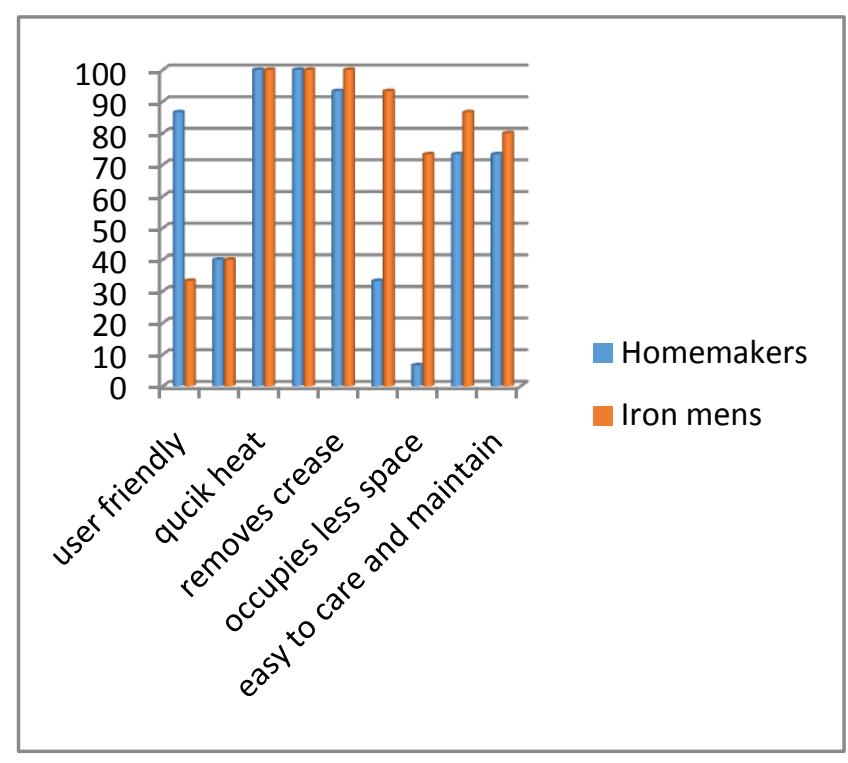

Fig.3. Performance of the device

\section{Conclusions}

The solar-powered iron box was efficient in ironing the clothes and helped homemakers \& iron men to acquire crease-free clothes. Solar-powered iron box not only uses solar energy which is available in nature free of cost but also reduces the consumption of energy. The present study may initiate households in adopting solar devices for day to day activates and encouraging them to use new and renewable sources of energy to protect our environment.

\section{References}

[1].Chauhan Pradip S. (2009) "Energy and Climate Change Issue ofSustainable Development", The Associated Publishers.

[2].Mr. UdayLokhande, (2010). A study of market penetration of solar equipments in Satara District, Submitted to Shivaji University, Kolhapur

[3].Cheryl (2008) "Demand, Technology, Tax Credits Drive Global Solar Power Growth", National Renewable Energy Laboratory, 2008.

[4].Project Management Team, MNRE (2010) "Solar Water Heaters In India: Market Assessment Studies And surveys for Different
Volume 03 Issue 01 January 2021

Sectors and Demand Segments", Greentech Knowledge Solutions, New Delhi-110078, India referred from www.greentechsolution.co.in

[5]. Sudha Mavuri (2011), "Impact of Education and Income on Awareness Creation and Buying Decision in case of Solar Products in Visakhapatnam, India", World Journal of Social Sciences, 1(1), pp. 49 -68 